\title{
MEMORIAL SOBRE A TRAJETÓRIA ESCOLAR BÁSICA DE SAMARA DOS SANTOS DA SILVA
}

\author{
Samara dos Santos da Silva ${ }^{1}$
}

Resumo: O presente texto trata do memorial sobre a trajetória escolar de Samara dos Santos da Silva, ex-integrante do Programa Conexões de Saberes. Tem como objetivo apresentar os passos percorridos desde o início da educação básica até a entrada à UFPA e quais os principais entraves de estudantes das comunidades populares adentrarem o ensino superior público. A memória foi usada como principal referência para construção do material. Em seus resultados, apresenta os esforços individual e coletivo para que de fato a educação seja uma questão de direito e não de privilégio de poucos.

"Só há duas maneiras de viver a vida A primeira é vivê-la como se os milagres não existissem A segunda é vivê-la como se tudo fosse um milagre”.

Albert Einstein

\section{EU}

Meu nome é Samara dos Santos da Silva, tenho 24 anos, sou natural do Estado do Maranhão da cidade de Caxias. A mais velha, dentre os quatro filhos, do matrimônio entre Pedrina dos Santos da Silva e Berto José Pereira da Silva, sendo que residi com eles somente nos primeiros anos de vida. Morei, dos seis aos quinze anos, com meus avós paternos, motivada pelos estudos, já que na cidade em que residíamos (Município de Gonçalves Dias, mais precisamente na localidade de Olho D’água Seco) a Educação Básica era precária, e pelo que presenciei recentemente continua sendo, com pouquíssimas melhoras, mas isto é outra história. Desde cedo, eles (os meus pais) me ensinaram que este seria o caminho que me levaria a galgar o que eu desejasse, inclusive não esqueço nunca o que meu pai me dizia sempre: "Minha filha! O seu namorado é o seu estudo".

Reporto-me agora, um pouquinho mais, a região onde convivi os primeiro anos de vida, realmente lá a vida não era fácil - não me recordo precisamente do ano - meu pai sai para trabalhar de manhã bem cedo na roça, minha mãe levantava ainda mais cedo, pois tinha que fazer o nosso café da manhã, arrumar a casa, as roupas, e seu trabalho era em dupla jornada, considerando que além de cuidar de mim e de minha irmã recém-nascida (que nasceu dois anos depois de mim) fazia alguns trabalhos na roça juntamente com meu pai, com "direito" a hora-

\footnotetext{
${ }^{1}$ Acadêmica* de Biblioteconomia da Universidade Federal do Pará, e-mail: san_samara@yahoo.com.br

* atualizado pela última vez em 2008.
} 
extra. Ainda me lembro que, Dona Pedrina, quando estava prestes a sair para o roçado, onde quebrava coco, entre outros trabalhos, para a nossa subsistência - me colocava na rede, deixando ao meu lado uma boneca de plástico, já um pouquinho usada e encardida (acredito que esta não foi vinda da loja direto para as minhas mãos), e embalava-me um pouco para pegar no sono, sob suas orientações: dizendo-me para eu ficar deitada até a hora em que ela retornasse e que não podia descer da rede, acho que realmente ela não acreditava que eu estava entendo todas suas recomendações, nem eu mesmo acho que entendia, mas, não sei como, obedecia. Ainda hoje quando lembro junto com ela desses momentos me diz que sempre fui a mais quieta e obediente, desde pequenininha, sendo este motivo de muitas risadas misturado às lágrimas.

Tudo era longe! Para qualquer lugar que se quisesse ir tinha que andar, e andar muito. Os vizinhos eram longe. O rio era longe. A cidade essa eu nem sei onde ficava. Mercearia ou comércio então, estes nem existiam, uma vez que nessa localidade as pessoas eram tão pobres que não compravam nada, então alguém que se aventurasse em colocar um ponto comercial por ali, logo se arrependia e fechava, além do que, tudo era caro! Num sabia exatamente o sentido do dinheiro ainda nesse tempo, mas escutava o meu pai falando alguma coisa em relação a isso, e reclamando da dificuldade de conseguir. Por isso, o prato principal e único era feijão com farinha, mas oh! Desse eu não reclamo, por que era bom demais o feijão da mamãe.

Após isso, o caminho percorrido não foi fácil, enfrentei muitas dificuldades, e a maior delas foi viver longe da minha família, enfrentei diversas outras, em especial no que diz respeito a minha educação, visto que, meus avós queriam que eu fosse educada da mesma maneira que eles foram, ainda mais tratando-se de mulher, que desde de sempre foi discriminada pela sociedade. Tendo que viver presa aos moldes sociais antiquados. Dizem que netos criados pelos avós são tolos ou mimados, mas estou entre as exceções, pois não fui nem um pouco mimada ao contrário, minha avó pouco demonstrava carinho, embora não possa afirmar, mas acredito que este fato se deve em virtude de sua educação rígida na qual os seus pais pouco demonstravam afeto.

Passei por situações que guardarei comigo e ninguém saberá, pois é triste relembrar, afinal dizem que relembrar é viver, e viver tudo isso de novo é tristeza demais. Apesar de todo este sofrimento também aprendi e hoje não sou tão forte como deveria ser, mas há em mim uma certeza de que tudo isso não foi e nem será em vão.

Revista PET Interdisciplinar e Programa Conexões /UFPA On-line. Ed. Especial - 2017, BELÉM/ PA - ISSN 2447-097X 


\section{FAMÍLIA}

Apresento a vocês meus pais: Berto José Pereira da Silva e Pedrina dos Santos da Silva ambos casaram-se muito novos, ele contava então com dezoito anos e minha mãezinha com apenas doze anos. São pessoas humildes, batalhadores, sem muitas instruções no que diz respeito a estudos, pois eles não concluíram sequer o ensino fundamental, mas com uma lição de vida enorme, que me fez lutar objetivando algo melhor, não só para mim, mas também para eles, pois, meu amigo, ter que trabalhar na roça, no pesado, quebrando coco e arando a terra não é fácil. Este tipo de trabalho foi fato marcante para que apenas concluíssem o nível de alfabetização, sustentando-se até hoje da agricultura.

Pouco tempo depois de casados minha mãe, ainda com 16 anos, percebeu que estava grávida e no dia 17 de julho de 1984, nasci, como já disse, a mais velha de 4 irmãos (Elionéia dos Santos da Silva, Keila dos Santos da Silva e Marcos dos Santos da Silva - o nosso marquinho). Neste percurso tenho também um irmão que se chama Waldemilson Alcântara de Sousa, filho de pai, apesar de não ter sido registrado por ele, criado pelos meus avós maternos.

Tanta dificuldade para criar os 04 filhos fez com que meu pai viajasse para outros estados e até mesmo para outro país a procura de trabalho para que pudesse nos sustentar, privando-se assim de viver/participar de momentos importantes das nossas vidas e deixando um vácuo o qual só é preenchido pela certeza do seu grande amor por nós, ele costuma dizer que em 28 anos de casado, vinte destes passou viajando. Tendo como companheira fiel, a minha mãe (Dona Pedrina), a flor mais bela, a pessoas mais íntegras que já conheci e de quem tento seguir como exemplo, a qual esteve e estará sempre ao nosso lado, educando, dando carinho e amor, às vezes uma tapinha de repreensão. Mãe como eu te amo.

Quando os meus pais relembram o que passou e me contam as histórias de suas vidas sinto-me orgulhosa por ser filha deles, pois são verdadeiros guerreiros, sobreviventes de uma batalha interminável, o dia-a-dia. Sei que para eles é um orgulho os filhos que eles têm e para nós uma verdadeira dádiva tê-los como nossos pais.

Abro um parêntese para deixar registrado que há pouco tempo minha mãe voltou a estudar e tem grandes expectativas para a sua formação educacional, deixo aqui também os meus parabéns a esta mulher maravilhosa.

Revista PET Interdisciplinar e Programa Conexões /UFPA On-line. Ed. Especial - 2017, BELÉM/ PA - ISSN 2447-097X 


\section{MEUS ESTUDOS}

Como havia dito, desde muito cedo fui morar com os meus avós, ocorreram alguns problemas e ainda na $3^{\mathrm{a}}$ série tive que voltar para o interior no qual meus pais moravam chamado Olho D’água Seco, a 100 km de Caxias, lá fui submetida a uma avaliação escolar e voltei para a alfabetização, isto atrasou um pouco a minha formação, mas agradeço à Professora Genésia, pois eu realmente não possuía condições de estar na $3^{\mathrm{a}}$ série, pois não sabia nem ler, e isso eu contava com quase 8 anos de idade. Três anos depois voltei a morar com os meus avós e dei continuidade a meus estudos normalmente na $3^{\circ}$ série do ensino fundamental com 11 anos de idade.

Permaneci com eles até os 14 anos, depois disso morei um ano na casa de uma tia, denominada Raimunda (esposa do meu tio Jacinto). Quando contava com 15 anos de idade, em dezembro de 1999, surgiu a oportunidade de morar em Belém, a muito contragosto desembarquei na capital paraense. Apesar de não querer ficar, novamente, veio aos meus pensamentos o ideal de estudar, e que nesta cidade teria mais chances de dar continuidade a meus estudos, fato este que realmente aconteceu, mas depois relatarei isso. Voltando aos fatos que contribuíram para a minha vinda para Belém, um deles como já havia dito foi o de estudar e o secundário de ajudar a minha tia Maria Antonia Santos de Alcântara (Irmã de minha mãe), que meses antes tinha dado a luz, desta forma, necessitando de alguém para ajudar a cuidar do seu filho pequeno, atualmente com 09 anos, e atende pelo nome de Denílson.

Foi uma mudança mais pelos meus pais, pois eles falaram que eu teria uma oportunidade de ter uma qualidade melhor nos estudos, sendo que o marido da minha tia (Manoel Marcos de Sousa) disse ao meu pai que faria o que fosse possível por mim, mas as mudanças nem sempre são tão agradáveis eu sofria muito pela distância dos meus pais, chorava muito.

Lembro-me que quando ia ao Maranhão e a uma semana de voltar ao Pará não conseguia comer direito e quando chegava aqui eu chorava por mais uma semana, demorou muito para que eu não sofresse tanto com esta distância, mas sempre tive o apoio da minha tia que me dizia que eu ia encontrar novos amigos e que eu iria gostar daqui.

\section{PERCURSO ESCOLAR}

Ao chegar a Belém para morar com parentes, fui matriculada em uma escola pública, para cursar a sétima série do ensino fundamental, próxima da casa de meus tios, que leva o 
mesmo nome do bairro Jaderlândia, em Ananindeua, devido a esta proximidade fazia o trajeto andando. Assim terminei o ensino fundamental. Para cursar o ensino médio fui matriculada na Escola, também pública, Pedro Amazonas Pedroso, com isso a situação ficou mais delicada, por que outro fator dificultava os meus estudos, o fator financeiro, já que a Escola situava na Avenida Almirante Barroso, e a passagem de ônibus em Belém, se tornava um empecilho, sendo que por diversas vezes faltei aula, pois não tinha o dinheiro da passagem, tampouco meus tios, pois contava com uma mesada mensal de meu pai, no valor de $\mathrm{R} \$ 100,00$ que dava pra pouca coisa, e isso quando ele podia mandar, mas graças a Deus, aos meus tios e a meus pais consegui concluir o ensino médio, embora com muitas dificuldades.

Numa tarde, idos do ano de 2004, deitada no sofá assistindo a novela malhação, tive uma sensação de estar perdendo tempo, foi aí, então, que eu resolvi estudar em um cursinho preparatório para a prova do vestibular do ano 2005 da Universidade Federal do Pará (UFPA), pois até então eu só concorreria a uma vaga desta instituição depois que terminasse o convênio. Já no fim do mês de agosto me matriculei no preparatório, em uma turma dita intensiva, que se localizava próximo da Escola onde estava concluindo meus estudos, porque iria possuir condições financeiras para arcar com o pagamento do cursinho e também com as passagens de ônibus, por isso eu estudava à tarde no cursinho e a noite ia para as aulas do convênio da Escola. Muitas vezes no intervalo do cursinho e da aula na Escola, não comia nada, pois novamente, me faltava o dinheiro, indo comer somente quando chegava em casa às onze horas ou até mesmo a meia noite. Apesar de tudo não desisti e fiz as provas, mas não acreditava que passaria, embora a demanda fosse pouca, porém as circunstâncias no qual eu vivia eram difíceis. Nesse período contei com um apoio muito importante que foi do meu namorado-amigo Dalson o qual me ajudou muito, inclusive foi ele quem viu o meu nome no listão da $1^{\mathrm{a}}$ e da $2^{\mathrm{a}}$ fases do vestibular, porque eu não tive coragem de olhar, tinha medo da decepção, depois que ele me disse fique muito feliz, mas ainda restava a terceira e última etapa e esta seria sem dúvida a mais difícil, pois era a prova discursiva, mas já me sentia uma vitoriosa só de chegar a terceira fase da prova, muitas pessoas com condições melhores e mais bem preparadas não figuravam nesta listagem. Fiz a $3^{\text {a }}$ fase e sai da sala muito cansada e sem muitas expectativas e sem fazer nenhum comentário, não queria nem se quer ouvir falar em vestibular.

O tão esperado dia chegado 19 de fevereiro de 2005 neste dia decidi que não ficaria em casa, existia muita tensão pra uma pessoa só, também não queria acompanhar a leitora do listão pela rádio, então combinei com o Dalson de irmos ao Centur (mais precisamente à biblioteca). Ele chegou lá bem cedo e eu ainda estava no ônibus quando a Klaúdia Cantanheide (irmã do

Revista PET Interdisciplinar e Programa Conexões /UFPA On-line. Ed. Especial - 2017, BELÉM/ PA - ISSN 2447-097X 
Dalson) me ligou dizendo que ele havia passado em Engenharia Elétrica e que eu também havia passado em Biblioteconomia e que era para eu ir ate a sua casa, por coincidência o ônibus passaria em uma parada próximo de lá e foi o que eu fiz, ligando em seguida para dar a notícia a ele e pedi que voltasse para sua casa. Com a sua chegada foi só festa com direito a ovos, massa de trigo, coloral e muita alegria. Depois de um tempo fui para casa e lá já sabiam da notícia e de um modo mais tímido tive o meu momento de comemoração em família com ovos, massa de trigo, fogos, choro, alegria e até cerveja. E aí, mais uma vez senti a ausência dos meus pais, mesmo em volto a tanta alegria da família, amigos, namorado ainda sim faltou o sorriso daqueles que me amam acima de tudo, contudo a festa continuou e foi churrasco na casa do Dalson e no fim de semana seguinte na minha casa e a chuva marcou presença, afinal festa de calouros sem chuva não existe.

Em março iniciou-se a habilitação e dias depois a matrícula, a partir dali seria iniciado um novo caminho no qual eu era estudante de Nível Superior da Faculdade de Biblioteconomia da Universidade Federal do Pará. É interessante que tudo muda, as pessoas passam a te olhar diferente, tanto em casa como na rua, entre os amigos é muito bom. Mas com essa vitória surgiram umas dificuldades e algumas indagações - como me manteria na universidade, como faria para comprar os livros, os textos e como poderia pagar 3 passagens por dia? (uma para ir a UFPA e duas para voltar para casa isso em decorrência do horário noturno). Foi nesse período que os meus tios me ajudaram ainda mais - confesso que nem sei como agradecer todo carinho e compreensão que sempre me dedicaram - e (graças a Deus!) ainda nos primeiros semestres de curso consegui um estágio na biblioteca da UEPA (Universidade Estadual do Pará) a bolsa - pouco mais de $\mathrm{R} \$ 200,00$ (duzentos reais) - foi de grande importância, pois com ela já não tinha que pedir aos meus tios o dinheiro da passagem de ônibus, nem para os dos textos e foi assim que fui me mantendo na universidade, sempre com a ajuda de todos que me amam. A partir daí fui pingando de estágio em estágio, passei palas bibliotecas da UFPA, tanto a central como a Setorial do centro de Educação (Hoje Instituto de Educação), além de ter estagiado também no Centur, onde cultivei grandes amizades e também obtive valorosos conhecimentos na parte específica do meu curso.

Numa noite um amigo me mostrou no quadro de aviso do meu curso o edital do programa Conexões de saberes: diálogo entre a universidade e as camadas populares/2007 o qual iriam fazer uma seleção de bolsistas, percebi que pediam muitos documentos os quais seriam difícil de conseguir visto que eu tinha quatro dias para recolher todo esse material, contudo resolvi tentar e ainda bem que deu tempo para tudo.

Revista PET Interdisciplinar e Programa Conexões /UFPA On-line. Ed. Especial - 2017, BELÉM/ PA - ISSN 2447-097X 
Estou um passo de terminar a minha graduação e sinto-me feliz pela oportunidade dada por Deus e aceita por mim, sei que tenho muito a apreender e que esta longa jornada não termina aqui, visto que os meus objetivos vão além da formação de docente em graduação. Sei também que por ser a filha mais velha sou vista muitas vezes como um "exemplo", não gosto deste rótulo, pois sei que não sou aluno de conceito excelente, mas em termo de dedicação e perseverança tenho lutado pelo que quero, e não quero ser comparada a ninguém, quero apenas que eles tenham sempre na consciência que assim como eu, eles podem ingressar e concluir o ensino superior quem sabe até com mais êxito.

Hoje às proximidades de minha formatura, posso dizer a eles: meus queridos de minh'alma, nada, absolutamente nada, que passamos e dificuldades que enfrentamos foram em vão! Muito obrigado por tudo que fizeram e por tudo que tentaram fazer por mim e por meus irmãos! Pagá-los não posso, pois é um preço imensurável todo esses desprendimentos, mas amá-los sempre irei!

\section{AGRADECIMENTOS}

Quero agradecer, primeiramente, ao Deus da minha vida que sempre esteve comigo e nunca me abandonou. Obrigada meu Senhor.

Agradecer a minha família pelo amor, compreensão e por consolar-me milhares de vezes que chorei e também por perdoar-me nos momentos de impaciência. Deus abençoe a todos nós e retribua com muitas bênçãos.

Quero agradecer os meus amigos e amigas do Curso Bacharel em Biblioteconomia da UFPA da turma de 2005/turno da noite, aos meus amigos da Igreja que sempre oraram por mim e ao meu namorado pela sua participação na minha vida.

A todos do programa Conexões de Saberes (UFPA), bolsista e coordenadores pela oportunidade de estar ao lado de vocês em um programa que sempre abre novos horizontes para todos que participam dele.

Não posso também, esquecer-me de agradecer a esta Cidade (Belém) que me acolheu, sendo que aqui encontrei subsídios necessários para alcançar e continuar lutando por meus objetivos.

Até aqui nos ajudou o Senhor ( $1^{\circ} \mathrm{SM}$ cap.7 v.12 parte b).

Revista PET Interdisciplinar e Programa Conexões /UFPA On-line. Ed. Especial - 2017, BELÉM/ PA - ISSN 2447-097X 